${ }^{\circledR}$ Entomologica Fennica. 5 December 1995

\title{
Emergence and upstream flight of lotic mayflies and caddisflies (Ephemeroptera and Trichoptera) in a lake outlet, central Finland
}

\author{
Pauli Bagge
}

Bagge, P. 1995: Emergence and upstream flight of lotic mayflies and caddisflies (Ephemeroptera and Trichoptera) in a lake outlet, central Finland. - Entomol. Fennica 6:91-97.

Temporal and spatial occurrence and upstream flight of lotic mayflies and caddisflies were studied by means of kick netting, slit traps and floating emergence traps in Lake Konnevesi and its outlet stream (Siikakoski), mainly in 1983. Twenty species of mayflies and 78 species of caddisflies were recorded. Clearly lotic mayflies in the material were Baetis subalpinus, Heptagenia sulphurea and Ephemerella mucronata, which occurred only in the stream samples. Females of lotic Baetis rhodani had a long distance upstream flight in the area and occurred frequently in the floating emergence traps especially in sandy littoral habitats of L. Konnevesi. Procloeon bifidum and Nixe joernensis, which in some regions occur mainly in streams, were frequently found in the stony littoral belt of L. Konnevesi. Most of the mayflies recorded in the area were univoltine, but Baetis rhodani and Centroptilum luteolum at least had two generations in 1983. Strictly lotic species among caddisflies were Ceratopsyche nevae, Hydropsyche saxonica, Halesus digitatus, Ceraclea perplexa, Ylodes detruncatus, Athripsodes commutatus and Hydroptila forcipata. These were mainly found in stream samples. A short distance upstream flight of females (c. $0.1-0.4 \mathrm{~km}$ ) was observed in the populations of $H$. siltalai, Psychomyia pusilla and Oxyethira frici and a moderate distance flight (at least $0.6 \mathrm{~km}$ ) by females of Hydropsyche pellucidula, Cheumatopsyche lepida and Polycentropus irroratus. The most abundant caddisflies of the stream Siikakoski (Brachycentrus subnubilus, Neureclipsis bimaculata, Rhyacophila nubila, Agapetus ochripes, Micrasema setiferum and Hydroptila cornuta) were frequently found also in floating emergence traps in the lake ( $3.7 \mathrm{~km}$ from the rapids). Females of Brachycentrus, Neureclipsis and Rhyacophila favoured traps on sandy substrata while females of Hydroptila were usually found in the stony belt. In the trap material of Agapetus ochripes, males were more abundant than females. According to emergence data, all caddisflies recorded in the area were univoltine though the emerging period of several species such as Rhyacophila nubila and Neureclipsis bimaculata was long. Maximum emergence was observed in early June when brachycentrids were swarming and another peak in August when limnephilids and leptocerids were abundant.

Pauli Bagge, Dept. of Bio- and Environmental Sciences, University of Jyväskylä P.O. Box 35, FIN-40351 Jyväskylä, Finland 


\section{Introduction}

In two earlier papers (Bagge 1987, 1992) dealing with the trichopteran fauna of Lake Konnevesi and its outlet stream Siikakoski, I have noticed a frequent occurrence of adults of some running water species in the floating emergence traps situated in the littoral zone of the lake.

In this paper, the emergence and upstream occurrence of adults of lotic mayflies and caddisflies will be presented in more detail. The material was caught mainly in 1983 and includes both adults and larvae, thus allowing an analysis of both spatial and temporal occurrence of lotic species in the lakestream gradient. Both the downstream drift of larvae and the upstream dispersal of adults have been considered essential factors in the colonization cycle of stream insects (cf. Müller 1954, 1982, Russev 1972, Madsen et al. 1977, etc.). However, the literature data on the length of the dispersal of mayflies and caddisflies are rather contradictory, depending mainly on the catching methods (cf. Sode \& WibergLarsen 1993). A wide dispersal of limnephilids and some hydropsychids especially has been observed in light catches (cf. Göthberg 1973, Svensson 1974 , Bagge 1982, etc.), while results of more passive methods such as Malaise-trapping indicate much weaker dispersal (Sode \& Wiberg-Larsen 1993). As stated by Sode \& Wiberg-Larsen (1993), the study of dispersal of stream insects is essential in the protection and restoration of streams, since many stream insects (e.g. short-winged and wingless species) have a low capacity for migration. The problem is most acute in regions where the distance between running water habitats is long or important habitats have been destroyed.

\section{Sampling methods and the study area}

Larvae of mayflies and caddisflies were sampled in the stream in September 1983 and 1988 mainly by means of kick netting (1 min. kicking) and with colonization bricks (together c. 30 samples). Kick net samples were also collected at ten localities in the stony littoral belt of Lake Konnevesi in MayAugust 1983.

Two types of traps were used in sampling imagoes and subimagoes in May 24-September
28, 1983 (Bagge 1987). The floating emergence traps, each covering $0.36 \mathrm{~m} 2$ were provided with a container of preservative (ethylene glycol) and were emptied once a week. The slit-traps, originally constructed by Kuusela and Pulkkinen (1978) for catching adult stoneflies, were also provided with a preservative and were emptied every tenth day. The location of the traps in the stream banks and in the littoral belt of the lake is presented in Fig. 1. Six of the ten floating traps were in the shallow stony belt, $0.2-3.1 \mathrm{~km}$ upstream from the rapids, and the other four were on the somewhat deeper sandy bottom $(0.2,0.4$, 3.0 and $3.9 \mathrm{~km}$ from the outlet stream). Five slittraps were installed on the stony bank of the stream and one trap on the stony shore of the lake c. $0.1 \mathrm{~km}$ upstream from the rapids.

The study area, which is situated in the southwestern corner of the lake, may be characterized as a relatively natural, undisturbed large outlet stream with a high mean flow and low concentration of both humus and nutrients (Table 1).

The stream is an important spawning area of several running water fishes including brown trout and grayling (Bagge et al. 1993) and harbours a rich fauna of filter-feeders and grazers in particular, but very few shredders.

\section{Results}

A total of 20 species of mayflies and 78 species of caddisflies were observed in the samples. The trichopteran and ephemeropteran fauna consisted of both lotic and lentic species, and several species such as Caenis horaria, Heptagenia fuscogrisea and many polycentropodids occurred abundantly in both lake and stream samples.

Lotic mayflies inhabiting the stream Siikakoski were Baetis rhodani, B. subalpinus, Heptagenia sulphurea and Ephemerella mucronata. Moreover, the lake material contained both larvae and subimagoes of Nixe joernensis and Procloeon bifidum, which in many areas are considered as running water species.

The lotic component in the trichopteran fauna was strong, comprising especially filter-feeders such as Brachycentrus subnubilus, Neureclipsis bimaculata and hydropsychids, scrapes such as Agapetus ochripes, Psychomyia pusilla and several Ceraclea 


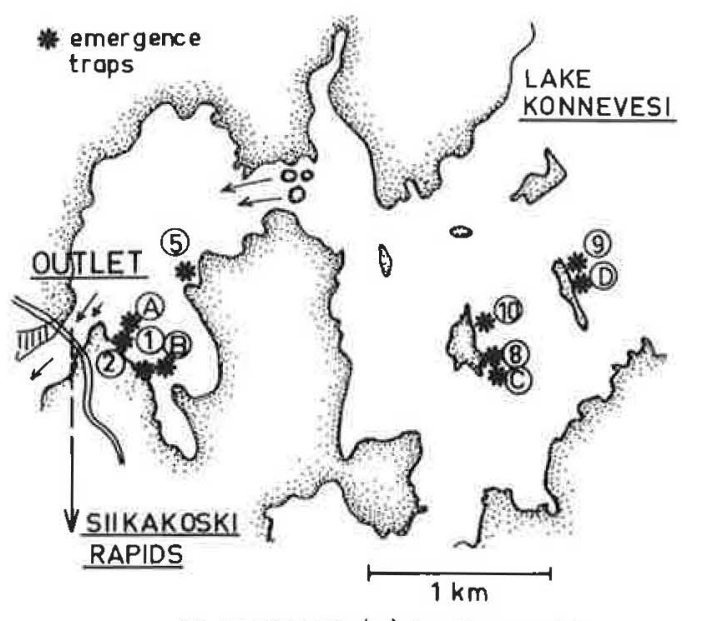

SLIT TRAPS $(\bullet)$ in the rapids

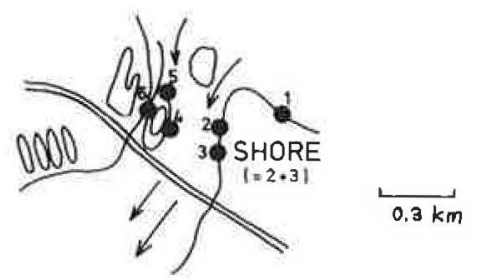

Fig. 1. Location of the traps in 1983.

spp., but only a few shredders (e.g. Halesus spp.). The larvae of these species were observed only in the stream samples, but adults of several species occurred frequently in the lake traps.

Table 1. Mean characteristics of the Siikakoski rapids during summer 1981 (Heinonen 1984).

\begin{tabular}{lcrr}
\hline Mean flow $\left(\mathrm{MQ}, \mathrm{m}^{3} / \mathrm{s}\right)$ & $100^{\circ}$ & $\mathrm{pH}$ & 7.2 \\
Temperature $^{\circ} \mathrm{C}$ & 15 & Colour $\mathrm{mgPt} / 1$ & 29 \\
$\mathrm{O}_{2}$-conc. $\mathrm{mg} / \mathrm{l}$ & 9.2 & Total N, $\mu \mathrm{g} / 1$ & 355 \\
Conductivity, $\mathrm{ms} / \mathrm{m}$ & 4.3 & Total $\mathrm{P}, \mu \mathrm{g} / 1$ & 9 \\
\hline
\end{tabular}

"Long term $M Q=43.5 \mathrm{~m}^{3} / \mathrm{s}$
The upstream dispersal of lotic mayflies and caddisflies

On the basis of adult material observed in the traps, four types of dispersal could be separated among the lotic mayflies and caddisflies.

1. species observed only in stream samples

2. species with a short distance upstream flight $(\leq 0.2 \mathrm{~km})$

3. species with a moderate distance upstream flight $(0.4-0.6 \mathrm{~km})$

4. species with a long distance upstream flight $(\geq 3 \mathrm{~km})$

Lotic species observed only in the stream (Table 2) included three common mayflies and five relatively rare caddisflies. The opposite to the case for other lotic mayflies in the group larvae of Ephemerella mucronata were relatively rare in the kick net samples in September 1983, but very abundant on colonization bricks in autumn 1989 (Hynynen, pers. comm.).

A short distance upstream dispersal $(<0.2 \mathrm{~km})$ was observed in the populations of Halesus spp. and Ceratopsyche nevae. Rare species perhaps belonging to this group were Ylodes detruncatus, and Ithytrichia lamellaris (Table 3).

A moderate distance dispersal $(0.4-0.6 \mathrm{~km})$ was observed in the populations of Hydropsyche pellucidula, H. siltalai and Cheumatopsyche lepida, which were abundant in the larval samples although numbers of the adults were low in traps (Table 3).

Adults of Psychomyia pusilla were abundant in the stream traps but relatively rare in the littoral zone of the lake. Rare species probably belonging to this group were Oxyethira frici and Polycentropus irroratus.

A long distance upstream flight $(\geq 3 \mathrm{~km})$ was observed in the populations of eight lotic species (Table 4). They were all abundant in the stream samples, with the majority of adults sampled in the

Table 2. Lotic species observed only in stream samples.

\begin{tabular}{|c|c|c|c|c|c|}
\hline & slarvae & $\Sigma a d$. & & Elarvae & $\Sigma$ ad. \\
\hline Ephemerella mucronata & 582 & 0 & Hydropsyche saxonica & 10 & 0 \\
\hline Baetis subalpinus & 46 & 1 & Ceraclea nigronervosa & 6 & 0 \\
\hline Heptagenia sulphurea & 40 & 1 & C. perplexa & 0 & 1 \\
\hline Athripsodes commutatus & 0 & 14 & Hydroptila forcipata & 0 & 1 \\
\hline
\end{tabular}


stream being males. Females dominated in the lake traps except in the populations of Agapetus ochripes.

A mass occurrence of mainly egg-bearing females of Brachycentrus subnubilus and Baetis rhodani was observed in lake traps on the sandy bottom c. 0.2 and $0.4 \mathrm{~km}$ upstream from the rapids. A further species favouring sandy areas was Rhyacophila nubila, while adults of Neureclipsis bimaculata and Hydroptila cornuta were usually found in the traps of the stony belt.

The position of Hydropsyche contubernalis in the group is somewhat problematic since there exists a strong stream population and a small lacustrine population preferring stony substratum.

Table 3. Lotic species with a short or moderate distance upstream flight $(<0.2-0.6 \mathrm{~km})$.

\begin{tabular}{|c|c|c|c|c|c|}
\hline \multicolumn{2}{|c|}{ Stream samples } & \multicolumn{4}{|c|}{ Lad. in lake traps } \\
\hline & arvae & इad. & $<0.2$ & 0.4 & 0.6 \\
\hline \multicolumn{6}{|l|}{ Short flight $(\leq 0.2)$} \\
\hline Ceratopsyche nevae & 29 & 13 & 3 & _ & _ \\
\hline Halesus digitatus & 0 & 27 & 3 & - & - \\
\hline H. tesselatus & 0 & 8 & 2 & - & - \\
\hline Ithytrichia lamellaris & 2 & 1 & 1 & - & _- \\
\hline Ylodes detruncatus & 2 & 1 & 1 & - & - \\
\hline \multicolumn{6}{|l|}{ Moderate flight $(\leq 0.6)$} \\
\hline Hydropsyche siltalai & 564 & 123 & - & 6 & - \\
\hline H. pellucidula & 392 & 32 & 8 & 2 & 7 \\
\hline Cheumatopsyche lepida & 78 & 34 & 4 & 6 & 2 \\
\hline Psychomyia pusilla & 3 & 124 & 14 & 2 & - \\
\hline Oxyethira frici & ? & 1 & 1 & 6 & - \\
\hline Polycentropus irroratus & 0 & 2 & - & - & 2 \\
\hline
\end{tabular}

Table 4. Lotic species with a long distance upstream flight $(0.2-3.7 \mathrm{~km})$

\begin{tabular}{|c|c|c|c|c|c|c|c|c|c|}
\hline & \multicolumn{2}{|c|}{ Stream samples } & \multirow[b]{2}{*}{$\begin{array}{r}\% \\
\text { males }\end{array}$} & \multicolumn{2}{|c|}{ Ead. in lake traps } & \multirow[b]{2}{*}{0.6} & \multirow[b]{2}{*}{3.0} & \multirow[b]{2}{*}{3.7} & \multirow[b]{2}{*}{$\begin{array}{r}\% \\
\text { males }\end{array}$} \\
\hline & Elarvae & इad. & & $\begin{array}{c}\text { Ead. in } \\
<0.2\end{array}$ & $\begin{array}{c}\text { lake traps } \\
0.4\end{array}$ & & & & \\
\hline \multicolumn{10}{|l|}{ Baetis } \\
\hline $\begin{array}{l}\text { Thodani } \\
\text { Brachycentrus }\end{array}$ & 59 & 1 & - & 412 & 769 & 40 & 33 & 23 & 0 \\
\hline $\begin{array}{l}\text { subnubilus } \\
\text { Neureclipsis }\end{array}$ & 1890 & 1847 & 85.5 & 4397 & 7246 & 5 & 443 & 32 & 0.2 \\
\hline $\begin{array}{l}\text { bimaculata } \\
\text { Agapetus }\end{array}$ & 135 & 1369 & 70.2 & 185 & 262 & 11 & 22 & 5 & 7.4 \\
\hline $\begin{array}{l}\text { ochripes } \\
\text { Rhyacophila }\end{array}$ & 197 & 250 & 62.4 & 12 & 3 & 0 & 0 & 5 & 79.0 \\
\hline $\begin{array}{l}\text { nubila } \\
\text { Hydropsyche }\end{array}$ & 22 & 286 & 45.5 & 20 & 27 & 1 & 11 & 0 & 1.7 \\
\hline $\begin{array}{l}\text { contubernalis } \\
\text { Hydroptila }\end{array}$ & 113 & 184 & 68.7 & 5 & 16 & 0 & 0 & 3 & 12.5 \\
\hline $\begin{array}{l}\text { cornuta } \\
\text { Micrasema }\end{array}$ & $?$ & 118 & 67.8 & 24 & 6 & 1 & 8 & 4 & 7.0 \\
\hline setiferum & 74 & 5 & 100.0 & 22 & 19 & 0 & 8 & 0 & 2.0 \\
\hline ¿traps & & 5 & & 3 & 2 & 1 & 3 & 2 & \\
\hline
\end{tabular}


Seasonal occurrence of adults of the most abundant lotic species in 1983

The total occurrence of lotic species in the traps had two maxima: one in June when brachycentrids and the first generation of Baetis rhodani were extremely abundant, and another in August when Neureclipsis bimaculata was abundant and the second generation of Baetis rhodani was flying (Table 5).

In July, the catches were small, although the number of species (especially hydroptilids) was relatively high. Autumnal catches were also small, consisting of species with a long flying period (Rhyacophila nubila, Neureclipsis bimaculata) or some late-emerging limnephilids (e.g. Halesus spp.).

Some lotic species occurred earlier in the stream traps than in lake traps; in the latter the maximum occurrence was detected relatively late. The early occurrence in the stream may depend on the excess of males, which usually emergence earlier than females.

Most of the lotic species recorded in the area were univoltine, whereas the emerging period was very long in the populations of Rhyacophila nubila and Neureclipsis bimaculata. Baetis rhodani and the lacustrine Centroptilum luteolum had two generations in the study area in 1983.

\section{Conclusions}

A rich ephemeropteran and trichopteran fauna (c. 100 species) was observed in a combined sampling of larvae and adults in the lake-stream

Table 5. Seasonal occurrence of Baetis rhodaniand the most abundant lotic caddisflies in stream (S) and lake (L) traps in 1983.

\begin{tabular}{|c|c|c|c|c|c|c|c|c|c|}
\hline Periods & & $\begin{array}{r}\text { May 24- } \\
\text { June } 6\end{array}$ & $\begin{array}{l}\text { June } \\
6-22\end{array}$ & $\begin{array}{r}\text { June } 22- \\
\text { July } 6\end{array}$ & $\begin{array}{r}\text { July } \\
6-22\end{array}$ & $\begin{array}{r}\text { July } 22- \\
\text { Aug. } 18\end{array}$ & $\begin{array}{l}\text { Aug. } \\
18-30\end{array}$ & $\begin{array}{l}\text { Aug.30- } \\
\text { Sept.14 }\end{array}$ & $\begin{array}{r}\text { Sept. } \\
14-28\end{array}$ \\
\hline Baetis rhodani & (L) & 120 & 435 & 467 & 45 & 181 & 12 & 9 & 4 \\
\hline Brachycentrus & (S) & 905 & 912 & 29 & - & 1 & - & - & - \\
\hline subnubilus & $(\mathrm{L})$ & 5679 & 6212 & 11 & 1 & - & - & - & - \\
\hline Micrasema & (S) & - & - & 5 & - & - & - & - & - \\
\hline setiferum & $(\mathrm{L})$ & 5 & 36 & 9 & - & - & - & - & - \\
\hline Agapetus & (S) & & 49 & 156 & 40 & 3 & 1 & - & - \\
\hline ochripes & $(\mathrm{L})$ & & - & 2 & 13 & 3 & - & - & - \\
\hline Ceratopsyche & (S) & & 7 & 4 & - & 2 & - & - & - \\
\hline nevae & (L) & & 1 & 2 & - & - & - & - & - \\
\hline Hydropsyche & (S) & & - & 27 & 36 & 15 & 5 & - & - \\
\hline contubernalis & $(\mathrm{L})$ & & 3 & - & 1 & 18 & 2 & - & - \\
\hline Hydropsyche & (S) & & 2 & 7 & 16 & 7 & - & - & - \\
\hline pellucidula & $(\mathrm{L})$ & & - & - & - & 11 & - & - & - \\
\hline Neureclipsis & (S) & & 4 & 351 & 58 & 526 & 104 & 14 & 3 \\
\hline bimaculata & (L) & & - & 7 & 25 & 400 & 22 & 29 & 2 \\
\hline Rhyacophila & (S) & & - & 15 & 8 & 45 & 111 & 20 & 94 \\
\hline nubila & (L) & & 1 & - & - & 16 & 8 & 9 & 22 \\
\hline Hydroptila & (S) & & 1 & 32 & 84 & 1 & 2 & - & - \\
\hline cornuta & (L) & & - & 2 & 3 & 38 & - & - & - \\
\hline Hydropsyche & (S) & & & 15 & - & 7 & - & - & - \\
\hline siltalai & (L) & & & - & - & 5 & 1 & - & - \\
\hline Psychomyia & (S) & & & 69 & 9 & 9 & - & - & - \\
\hline pusilla & (L) & & & 7 & - & 9 & - & - & - \\
\hline Cheumatopsyche & (S) & & & 4 & 14 & - & - & - & - \\
\hline lepida & (L) & & & 1 & 2 & 6 & 2 & - & - \\
\hline Halesus & (S) & & & & & & & & 27 \\
\hline digitatus & (L) & & & & & & & & 1 \\
\hline
\end{tabular}


gradient. The sampling was useful for taxonomical reasons and in study of the spatial and temporal occurrence of the different species.

The traps used in catching adults were somewhat selective and thus affected on the results. The slit-traps (model Kuusela \& Pulkkinen 1978) were ineffective in catching Hydropsyche spp. and mayflies, while the floating emergence traps were ineffective e.g. in catching subimagoes of Caenis horaria.

In the ephemeropteran fauna of the stream, the lotic component was weak (4 species), but some "rheophilous" species such as Nixe joernensis and Procloceon bifidum occurred frequently in the stony littoral zone of the lake.

In the trichopteran fauna, the lotic component was strong especially for filter-feeders: Brachycentrus subnubilus, Hydropsyche spp. and Neureclipsis bimaculata had high densities, while the abundance of shredders was low.

A long distance upstream flight ( $\geq 3 \mathrm{~km}$ ) of adults was observed in the populations of Baetis rhodani and 7 species of caddisflies which all were abundant in the stream samples, as well. Species mainly found in the traps on sandy littoral zone were Brachycentrus spp., Baetis rhodani and Rhyacophila nubila, while females of Neureclipsis and Hydroptila cornuta occurred mainly in the traps of the stony belt.

A short or moderate distance upstream flight was observed in the populations of Hydropsyche spp., Cheumatopsyche lepida and Psychomyia pusilla, and no upstream flight in the populations of three common lotic mayflies.

Compared with the literature data (cf. Sode \& Wiberg-Larsen 1993), the dispersal of Hydropsyche spp. and Halesus spp. especially was weak in the study area, but this may simply reflect differences in catching methods.

With a few exceptions (e.g. Rhyacophila nubila), males were in excess in the adult material of the stream, while mainly females were observed in the lake traps. However, in the catches of Agapetus ochripes, males were in excess also in the lake material, a fact in concordance with the sex-ratio in a Danish brook population of A. fuscipes (Sode \& Wiberg-Larsen 1993).

The abundant occurrence of egg-bearing fe- males in particular in the lake traps supports Müller's colonization cycle hypothesis (Müller 1954, 1982). In this case it may be a question of a prolonged upstream dispersal of females.

\section{References}

Bagge, P. 1982: Caddisflies (Trichoptera) and water bugs (Heteroptera, Corixidae) of small water bodies caught by light trapping in southeastern Finland. - Notulae Entomol. 62:73-81.

- 1987: Emergence and distribution of Hydroptilidae in the littoral and outlet biocoenoses of Lake Konnevesi (Central Finland). - In Bournaud, M. and Tachet, H.(eds.): Proc. 5th Int. Symp. on Trichoptera. Junk, Dordrecht, pp. 337-341.

- 1992: Communities and habitats of filter feeding caddisflies in the lake outlet biocoenoses of Central Finland. - In Tomaszewski, C. (ed.): Proc. 6th Int. Symp. on Trichoptera. Adam Mickiewicz Univ. Press, pp. 95-99.

Bagge, P., Takkunen, T. \& Valkeajärvi, P. 1993: The fish fauna and the densities of juvenile and young brown trout in the outlet streams of the Rautalampi lake system from 1983-1990. - Suomen Kalatalous 59: 21-31 (in Finnish, English summary).

Göthberg, A. 1973: Dispersal of lotic Trichoptera from a north Swedish stream. - Aquilo. Series Zoologica 14:99-104.

Heinonen, P. 1984: Early warning of eutrophication in rivers by analysis of periphyton chlorophyll $a$. - In Pascoe, D. and Edwards, R. W. (eds.): Freshwater Biological Monitoring. Pergamon Press 1984, pp. 45-52.

Kuusela, K. \& Pulkkinen, H. 1978: A simple trap for collecting newly emerged stoneflies (Plecoptera). Oikos 31:323-325.

Madsen, B. L., Bengtson, J. \& Butz, I. 1977: Upstream movement by some Ephemeroptera. - Arch. Hydrobiol. 81:119-127.

Müller, K. 1954: Investigations on the organic drift in North Swedish streams. - Drottningholm Inst. of Freshwater Res. Rep. 35:133-148.

- 1982: The colonization cycle of freshwater insects. Oecologia (Berlin) 52:202-207.

Russev, B. 1972: Über die Migration von Rheobionten in Fliessgewässern. — Verh. Int. Ver. Limnol. 18:730734.

Sode, A. \& Wiberg-Larsen, P. 1993: Dispersal of adult Trichoptera at a Danish forest brook. - Freshwater Biology 30:439-446.

Svensson, B. W. 1974: Population movements of adult Trichoptera at a South Swedish stream. - Oikos 25:157-175. 


\section{Appendix: List of lotic mayflies and caddisflies recorded in the study area}

\section{Ephemeroptera}

Baetis rhodani (Pictet)

$B$. subalpinus Bengtsson

Centroptilum luteolum (Müller)

Ephemerella mucronata (Bengtsson)

Heptagenia sulphurea (Mïller)

Nixe joernensis (Bengtsson)

Procloceon bifidum (Bengtsson)

Trichoptera

Agapetus ochripes Curtis Athripsodes commutatus (Rostock)

Brachycentrus subnubilus Curtis

Ceraclea nigronervosa (Retzius)

C. perplexa (McLachlan)

Cheumatopsyche lepida (Pictet)
Ceratopsyche nevae (Kolenati)

Halesus digitatus (Schrank)

H. tesselatus (Rambur)

Hydropsyche contubernalis McLachlan

H. pellucidula (Curtis)

Hydropsyche saxonica McLachlan

H. siltalai Döhler

Hydroptila cornuta Mosely

H. forcipata (Eaton)

Ithytrichia lamellaris Eaton

Micrasema setiferum (Pictet)

Neureclipsis bimaculata (Linnaeus)

Oxyethira frici (Klapálek)

Polycentropus irroratus (Curtis)

Psychomyia pusilla (Fabricius)

Rhyacophila nubila (Zetterstedt)

Ylodes detruncatus (Martynov) 